\title{
Research
}

\section{Company-Community Logging Contracts in Amazonian Settlements: Impacts on Livelihoods and NTFP Harvests}

\author{
$\underline{\text { Mary C.S. Menton }}^{1}$, Frank D. Merry $^{2}$, Anna Lawrence $^{3}$, and Nick Brown $^{1}$
}

\begin{abstract}
As a result of government-sponsored colonization, more than $500000 \mathrm{~km}^{2}$ of the Brazilian Amazon is managed by settlement households. By law, $80 \%$ of this land must remain as standing forest. In this study, we examine the potential for timber harvesting through company-community partnerships (CCPs) as a means to increase forest-based revenue without compromising household use of non-timber forest products (NTFPs). Using participatory rural appraisal, resource diaries, and household questionnaires, we study the impacts of CCP logging contracts on livelihoods, including household income and NTFP harvests. Our results show that annual household income from the CCP logging is equivalent to more than 8 years of household gross income from agricultural production. We also found that there were no significant differences in NTFP harvests between households with CCP logging and those without. In CCP-logging communities, households caught $11.9 \pm 13.6$ game animals, totaling $74 \pm 88 \mathrm{~kg}$ of game meat. In the communities without $\mathrm{CCP}$, households caught $9.5 \pm 13.0$ game animals, totaling $73 \pm 172 \mathrm{~kg}$ of game meat. Annual forest fruit harvests averaged $9.8 \pm 13.2 \mathrm{~kg}$ in CCP-logging communities and $13.5 \pm 15.9 \mathrm{~kg}$ in non-CCP communities. Overall, the CCPs brought improvements in household income without compromising NTFP harvests.
\end{abstract}

Key Words: Amazonian frontier; non-timber forest products; rural livelihoods; sustainable forest management

\section{INTRODUCTION}

The first wave of colonization of the Brazilian Amazon began in the 1970s with the National Integration Plan (PIN) and construction of the Transamazon Highway (Smith 1982, Moran 1996). Currently, the Brazilian government continues to settle families on as-yet unclaimed public forested lands ("terra devoluta"). By 2002, the National Institute for Colonization and Agrarian Reform (INCRA) had settled 528571 families in the Legal Amazon region (Barreto et al. 2005), 320000 of whom were settled between 1994 and 2001 (Ministério do planejamento, orçamento e gestã 2002). With formal landholding sizes at $100 \mathrm{ha}$, these settlements covered an estimated $528571 \mathrm{~km}^{2}$. In addition, Lima et al. (2006) estimate that informal settlement may almost double the number of settlers in a region. Even though the exact extent of land holding by colonist settlers and other smallholders is unclear, these estimates indicate that they may hold $8 \%-16 \%$ of land in the Brazilian Amazon. As such, strategies for sustainable development of the region should include these smallholders as part of any conservation planning (Campos and Nepstad 2006). Furthermore, federal laws state that $80 \%$ of land holdings must remain as permanent forest reserve. Although in practice many land holdings have already been deforested beyond the $20 \%$ limit and significant areas of current $80 \%$ reserves are likely to be felled due to ineffective policing of these areas, the government's emphasis on maintenance of standing forest puts added importance on development projects that increase revenues from standing forest. As many new settlement areas contain large expanses of intact forest, forest management may play an increasing role in government-supported development strategies within settlement communities. Yet, studies of the potential role of forest management in settlement communities are rare (but see D' Oliveira et al. 1998, Sá et al. 1998, Vosti et al. 2003, Bentes-Gama et al. 2006, D'Oliveira and Braz 2006, Humphries and Kainer 2006). 
One exception is the independent Family Forests (FF) project, a forest management project based on company-community logging contracts that has been advocated as a model for equitable sustainable development in settlement communities across the Amazon (Lima et al. 2003, Nepstad et al. 2004a, b, Merry et al. 2006). The FF Project is examined here in terms of the implications of companycommunity forest management partnerships on livelihoods in settlement communities. Companycommunity partnerships (CCPs) have recently been proposed as a means for community involvement in the forestry sector that uses market mechanisms to work without donor funding (Mayers et al. 2002). These partnerships typically involve a variety of activities, including out-growing for pulpprocessing firms or supplying roundwood, with varying levels of community participation in the forest management process (Mayers et al. 2002). Although in the presence of unequal information or immediate cash requirements, company-community interactions have the potential to be exploitative or paternalistic (Medina and Shanley 2004), positive examples of CCP are emerging (Mayers et al. 2002, Rival 2005). Considering the socioeconomic and political impediments to sustainable forest management in the Amazon, effective collaboration, whether through CCP or other civil society coalitions, may be a necessity for successful forest management (Ros-Tonen et al. 2008).

Although the aforementioned studies have focused on the livelihood impacts of CCP, few include an assessment of the effect on the use of non-timber forest products (NTFPs, which include both animal and plant-based products). With the removal of individual trees and the alteration of forest structure and access, the potential impacts of logging on availability of NTFPs could have important effects on rural livelihoods. Although NTFPs were once put forth as a panacea for sustainable development in the tropics (Ruiz-Perez and Arnold 1996, Assies 1997, Wollenberg and Ingles 1998), further analysis has revealed that economic cycles (Crook and Clapp 1998), efforts to domesticate NTFP species (Homma 1996), and unsustainable harvest levels (Vasquez and Gentry 1989) may threaten their longterm viability as an integrated conservation strategy. As a result, NTFPs are not the "quick-fix" they were once thought to be (Lawrence 2003). Nevertheless, NTFPs often form a critical part of rural household livelihood strategies. One study of rural households in the Brazilian Amazon found that NTFPs accounted for $25 \%$ of annual income (Shanley
2000) whereas another study found that they accounted for 33\% (Wallace 2004). Although not all households are as dependent upon NTFPs, and for some, they constitute a smaller percentage of overall food consumption, their role in subsistence and as a buffer in times of food shortages often makes them a critical component of food security for rural populations (Lipper 2000, Pattanayak and Sills 2001). As a result, they merit further study.

Although several studies provide important information regarding the social, economic, and ecological effects of logging (e.g., Uhl et al. 1991, Watson 1996), the potential changes in NTFP harvests after timber extraction have received little attention. With some notable exceptions (e.g., Laird 1995, Salick et al. 1995, Shanley 1999, Shanley et al. 2002, Menton 2003, Guariguata et al. 2008), most of the literature on NTFPs does not address both logging and NTFP extraction. As a result, the extent and direction of these impacts are poorly understood. In addition, because forest management exclusively for NTFP extraction may not be economically viable under current market conditions, research into the interplay between logging and NTFP species can contribute to integrated, multipurpose forest management. Although other studies have looked at logging in settlements (see above), this study is unique in that it links logging, NTFPs, and colonist livelihoods.

After describing the FF project, we present results from a study of the impacts of participation in FF on livelihoods and NTFP harvests. Whilst forests have many values beyond a direct-use and monetary value, the current study is based on utilitarian valuation of forest resources, emphasizing NTFP harvests and timber revenue. Other concepts of forest valuation and importance in the study communities are discussed elsewhere (Menton 2006). Comparing households in communities that participated in $\mathrm{FF}$ with those in communities that did not participate, we evaluate differences in NTFP harvests via analysis of hunting behaviors and success rates, and fruit and nut harvests. Another study (Menton 2006) showed that other NTFPs (e. g., medicinal plants, construction materials) were harvested in very small quantities and, therefore, are not included here. An assessment of household income and investment of logging income follows. We make use of an intensive data-collection process that covered more than 18 months of field work with the communities and complementary methods to ensure more complete coverage of the topic. We 
show that, overall, the FF model of CCP logging provides economic benefits to frontier households and merits further study regarding its potential contribution to economic development on the forest frontier.

\section{STUDY SITE}

\section{Description of Family Forests}

The FF Project is being implemented in the INCRA settlements of Moju I and II, approximately $100 \mathrm{~km}$ south of Santarém, Pará, to the east of the BR-163 highway (Fig. 1). The project is based on companycommunity contracts whereby timber is harvested by a small timber-harvesting company, Manejo Florestal e Prestação de Serviços (MAFLOPS; Forest Management and Service Provider). In communities that express an interest in participating in the logging project, a community association is formed of individual households who sign contracts with MAFLOPS. Most of the families do not have legal title to their land (80-100 ha) and others lack even the "protocolo," a government document that serves as a temporary land title until the official legalization process has been completed. In such cases, the company helps the households apply for a "protocolo" from INCRA. Although land title should be granted within 3 years of settlement, most households wait longer for their title as a result of government bureaucracy. Twelve percent of land titles in Moju I and II were held by women.

Once demarcation is completed, harvesting is done in two different phases: (1) harvest of commercial timber felled from forest areas cleared for agricultural production, and (2) trees from the permanent forest reserve are harvested using reduced-impact logging (RIL) techniques (see Pinard et al. 1995, Johns et al. 1996, Barreto 1998). These activities require a deforestation permit for harvest on cleared land and a forest management plan for the permanent forest reserve. For both harvest options, the landowner must secure authorization from the Brazilian Institute for the Environment and Renewable Natural Resources (IBAMA). The area cleared in any given year is determined by the individual household but cannot exceed the legal limit of 3 ha per year and can continue annually up until $20 \%$ of the total land has been cleared. The area is cleared and any commercially viable timber is harvested by MAFLOPS, which pays a stumpage fee to the landowner. Distribution of logging income to spouses or other family members is controlled by the landowner.

For harvesting in the permanent forest reserve, MAFLOPS performs an inventory of all commercial and potentially commercial trees with a diameter at breast height $(\mathrm{dbh})>45 \mathrm{~cm}$ within the plot and develops a management plan for approval by IBAMA. Once the plans have been approved by IBAMA, MAFLOPS can begin harvesting in the following dry season (July-December). Harvest intensity is in the order of $13-18 \mathrm{~m}^{3} \mathrm{ha}^{-1}$ and includes 50 different tree species. The households within a given community are divided into three to four annual logging units. Communities are responsible for determining the order in which landholdings will be logged. Some communities determined the order such that the neediest households were first to log whereas others chose the order via a lottery. All timber-harvesting activities (including pre-harvest planning and post-harvest transport) are the responsibility of MAFLOPS, and it pays each household a stumpage fee based on the actual harvests on their land. Harvesting is done based on the premise of a 20-year rotation and households are paid in one large sum. Household heads are encouraged to be present during the felling on their lands so as to verify the total amount of timber harvested. In addition, if he or she wishes that any given tree be left standing, the company will comply. In practice, however, few households chose to have an individual present during the logging or to make demands regarding particular trees.

Household income from the harvests on clearings averages $\mathrm{R} \$ 1000$ a year (US\$341; average exchange rates for $2004: £ 1.00=\mathrm{R} \$ 5.36$, US $\$ 1.00=$ $\mathrm{R} \$ 2.93$, www.oanda.com) and varies from $\mathrm{R} \$ 6000$ to $\mathrm{R} \$ 20000$ for harvests in the forest reserve $(80 \%$ of their land). Income has risen steadily each year. Prices are determined by the logging company based on market values and harvest costs in the given year. In 2004, MAFLOPS paid R $\$ 16$ per cubic meter. Other communities in the Amazon have been reported to sell trees (stumpage fees) for as little as $\mathrm{R} \$ 10$ a tree (Shanley and Medina 2005) or as much as $\mathrm{R} \$ 60$ per cubic meter (S. Humphries, unpublished data). According to MAFLOPS' managers, they pay a low price because they have to rent equipment from another larger logging company (CEMEX), and thus harvest costs are high. In addition, although access roads should already have been built by INCRA as part of INCRA's 
Fig. 1. Study site and region.

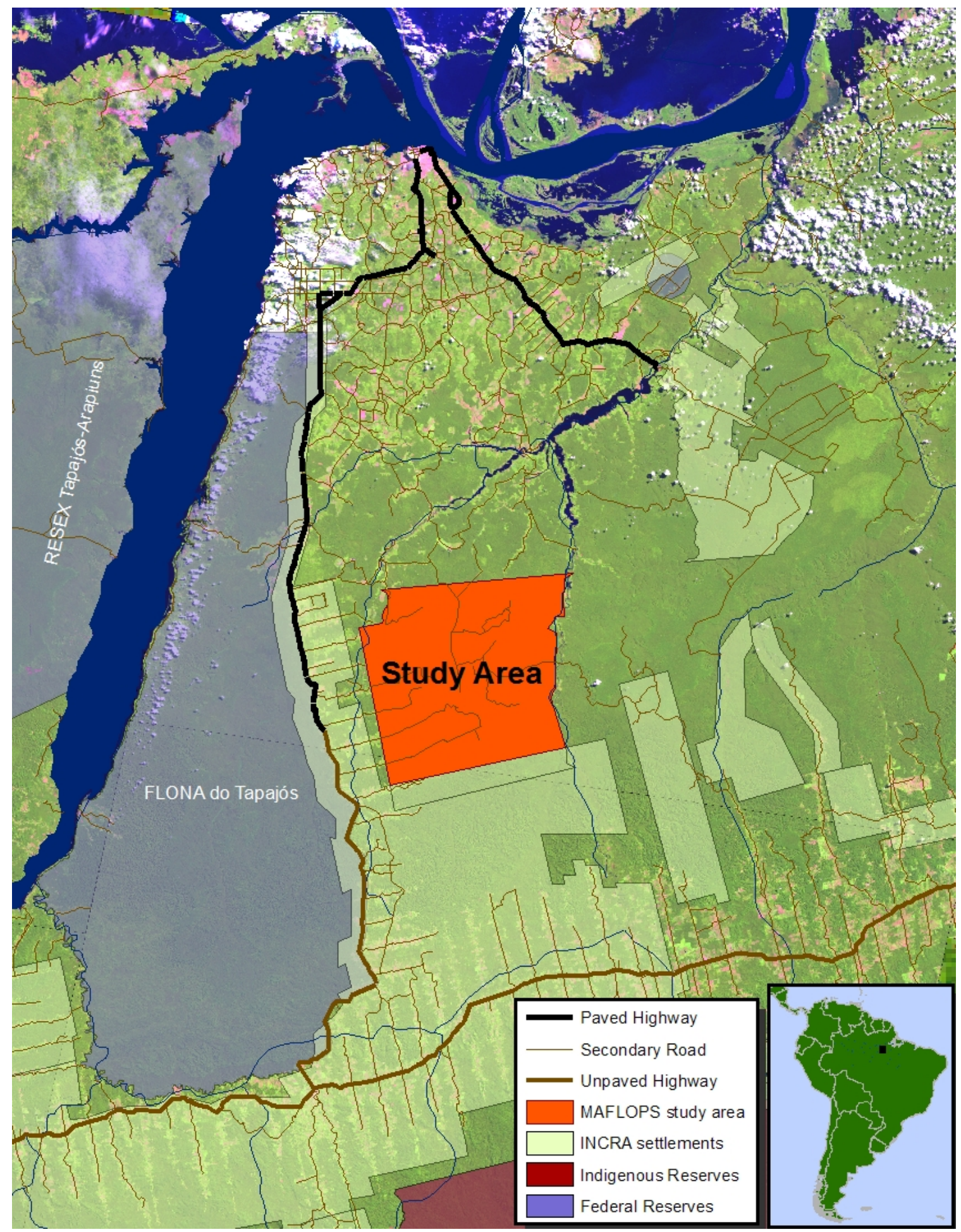


colonization scheme, many communities lack road access. As a result, MAFLOPS cites the construction of primary and secondary roads, necessary for the timber harvest, as another factor that leads households to receive an even smaller payment for their timber.

\section{Study Communities}

Before the start of this study, collaborators from the Amazon Institute of Environmental Research (IPAM) conducted an extensive socioeconomic questionnaire throughout Moju I and II to get background data on livelihood parameters, household economics, and use of forest resources (Merry et al. 2004). Five communities (Table 1) were chosen for this study in consultation with the field team that distributed the questionnaires. The $\mathrm{CCP}$-logged communities were chosen as they were the only communities where logging had already taken place by spring 2003. The non-CCP communities were chosen because of their location in relation to the CCP-logged communities such that they were far enough away so as to be unlikely to be affected by the logging but close enough so as to have similar forests and infrastructural conditions.

In all of the communities, key-informant interviews reported previous illegal logging activities in the communities' forests such that they had all experienced some sporadic, low-intensity, highly selective logging before establishment of the settlement community. Some illegal logging was also reported to be happening within the Moju I and II settlements at the time of the study. Although potential harvest income from these forests is thus lower than that of a virgin forest due to "mining" of high-value timber species (e.g., Tabebuia sp.), forest structure remained largely intact due to the sporadic nature of the illegal logging activities.

In each community, the president of the community or community association was contacted to seek authorization for the research and to arrange for a community meeting to present the research and seek informed consent before the start of the study (see Laird and Posey 2002). At this meeting, the objectives of the study and the degree of participation that would be required were made clear. After much discussion, each of the communities agreed to participate in the study.

\section{METHODS}

Three different methodological approaches were used in order to obtain a holistic assessment of the impacts of CCP logging on NTFP use and household livelihoods: participatory workshops, resource-use diaries, and household questionnaires. Participatory workshops provided local perspectives on research questions. Resource-use diaries provided seasonal data on agricultural production and NTFP harvests. Household questionnaires provided quantitative data on labor allocation, hunting activities, and household income.

\section{Participatory Workshops}

Participatory workshops were held in each of the study communities to explore their use of NTFPs and the effects of logging on resource use and livelihoods. Workshops were chosen as a methodology as they allowed the research team to gain an overview of community opinions in a short period of time. The presence of representatives of different households promotes the inclusion of differing viewpoints as participants work toward a consensus. Workshops are, however, prone to certain biases as not all community members participate and the more vocal or more powerful members may dominate discussions (Cooke and Kothari 2001). Participation of a variety of community members was promoted in order to minimize dominance by the powerful minority. Before holding workshops, a general invitation was sent to the community and, during data-collection visits, individual households were invited to participate. Although participation was on a voluntary basis, all community members were encouraged to attend. On average, $40 \%$ of the participants were female. Although participants in the workshops may not be a truly representative cross-section of the community as the more active households are more likely to attend, a truly representative sample would be nearly impossible under voluntary participation. Transportation was provided for families who lived far from the community center so as to avoid bias and encourage inclusion of all members of the community. The decision to participate in any given workshop was based on the participant's interest in the subject and, perhaps much more importantly, his or her availability on the day of the workshop. 
Table 1. Community age, size, and company-community partnership (CCP) status.

\begin{tabular}{lccc}
\hline \hline Community & Founded & Number of Households & Logging Status \\
\hline Anta & 1999 & 63 & CCP logged \\
Piranha & 1998 & 104 & non-CCP \\
Santo Antonio & 1999 & 29 & CCP logged \\
São João & 1992 & 50 & non-CCP \\
São Mateus & 1984 & 38 & non-CCP \\
\hline
\end{tabular}

In a series of participatory workshops (two per community), participants discussed resource use and the impacts of the CCP logging on said use and on livelihoods in general. In the large group, a list of the costs and benefits of the logging was compiled. Participants were asked to offer any benefits gained or problems caused by the CCP logging. After compiling a comprehensive list, each cost and benefit was then discussed in greater detail. At the end of the workshop, they were asked to vote on whether or not the CCP logging was worthwhile overall. Finally, recognizing the importance of returning results to local communities (Shanley and Laird 2002) as a means to both share results and receive local feedback and explanations for those results, a results presentation meeting was held in each community in July 2005. Their responses to and discussion of research results were recorded and are used here.

\section{Resource-Use Diaries}

Resource-use diaries were used as a means to get accurate, detailed information regarding household resource use and agricultural production and sales. Diaries provide information not only on farm-based income but also on subsistence use of farm and forest resources, factors that are often underestimated in studies of household economics (Cavendish 2002). As participatory rural appraisal (PRA) methods have the disadvantage of often aggregating information at a community level (Dovie 2003), household-based data is an important means of addressing inter-household heterogeneity (McSweeney 2002). Although resource (time/cash) intensive, use of diaries has been promoted as a means to gain detailed data on resource use (Grieg-Gran et al. 2002).

A random sample of households was chosen to record resource use in diaries. Households were chosen using two different methods. First, a random subset of houses along community roads were visited - the first house was selected by choosing a random distance $X$ and stopping at the first house after distance $X$ was travelled. Subsequent houses were visited by choosing a random number $Y$ from 1-5 and travelling $Y$ houses before stopping again. If the house was empty, the next house along the road was visited. An overview of research objectives and methods was given at each visit and participation of the household solicited. If the family agreed, they were given a notebook to begin collecting data. Other households were included in the survey through soliciting volunteers at an introductory community meeting. The objectives of the study were explained and a list of interested households made, selecting participant households at random out of a hat. Originally, 60 households were given diaries. By the end of over a year of data collection, 50 remained actively involved in the survey. Loss was due largely to family absence from the community (either because they moved $(n=2)$ or resided almost exclusively in the city but had indicated otherwise upon joining the research project $(n=6))$, but two dropped out because of disinterest in the study. 
Each household was given two scales, one to measure small goods up to $12 \mathrm{~kg}$ and the other to measure goods up to $120 \mathrm{~kg}$, a notebook, pens, and bags (for weighing). Household heads (with assistance of a chosen representative when heads were illiterate) were trained in how to use the scales and how to record the data. Where possible, both male and female heads were trained. In most households where a female was present, women usually took most of the responsibility for recording data. They were asked to record the following: date, product, quantity (e.g., number of game animals, number of eggs), mass (kg), and origin (forest vs. field). Examples of product records were included in each notebook. The importance of recording small quantities (e.g., a handful of leaves for tea, medicinal bark, a few small fruits, etc.) was emphasized. For products weighing less than $0.5 \mathrm{~kg}$, participants were asked to estimate the total weight as the scales provided did not have sufficient precision to measure small quantities.

During the first 2 months of the study, households were visited every 2 weeks by the research team in order to transfer data to our records and answer any questions regarding the recording process. The following 2 months, they were then visited only monthly. We found, however, that monthly visits were too infrequent-many items were forgotten and some families assumed we "weren't coming back" and stopped data collection altogether. As a result, households were visited fortnightly for the remainder of the data collection, and data analysis is based on 14 months of data (November 2003December 2004). Frequent visits were especially important as most families travel to Santarém (nearest market city) at least two times a month, which often led us to miss them on at least one datacollection trip per month. If visits were only done monthly, families could go 2-3 months without receiving a visit by the team.

A large percentage of the households were illiterate or semi-literate and independent recording of resource use was difficult. As a result, resource use was often recorded by the data-collection team during the fortnightly visit, giving respondents a chance to recall all of their production, sales, and consumption during the previous 2 weeks. Diary records may have been influenced by the collection process. As the households were asked to recall their activities over a 2 -week period, it is likely that some smaller harvests were forgotten. In addition, as in any measurement of resource use, results depend on the honesty of respondents in their reporting. As such, it is possible that some records were underreported, especially for illegal activities, whereas others may represent exaggerations about the size of harvests. Literacy levels (which were not significantly different among the colonist communities-Kruskal-Wallis, $\mathrm{X}^{2}=4.003$, $\mathrm{df}=4$, $p=0.261$ ) may also influence recording practices as illiterate families were more likely to depend on the data-collection team and thus may have been more susceptible to problems with recall. Although these factors may bias results, the bias should be relatively consistent across communities such that community participation in logging does not confound a respondent's tendency to report resource use accurately or honestly.

\section{Household Questionnaires}

Starting in January 2004, household heads were questioned regarding their household activities over the last 2 weeks during each resource-diary collection visit. They were asked whether or not they hunted and, if so, the number of trips, hours spent, and the animals caught. A total of 860 biweekly interviews were held with 57 different households. Hunter effort for each community was calculated for each hunter as the mean of total time spent hunting divided by total number of animals caught.

With each of the participant households, a survey on hunting and domestic animals was undertaken from September to November 2004. An inventory of their livestock and other domestic animals was taken in addition to a survey of their hunting behaviors, including frequencies, species hunted, and success rates. All but three of the respondents $(n=41)$ were male as hunting was a predominantly male activity. After preliminary results were analyzed, certain gaps in information were identified. In addition, quantifiable information regarding the CCP logging project was lacking. As a result, a supplementary survey was developed to address these issues. Forty-two participant households were interviewed regarding: income from the timber harvest, expenditures of logging income, attitudes toward the CCP logging project, and history of occupation and migration. 


\section{RESULTS}

The results presented below are from a combination of the three data-collection methods used in the research. Although households used a variety of NTFPs (see Table 2), we focus on two principal components of NTFP collection: hunting and forest fruit. We then examine the perceived impact of CCP logging and the destination of the income earned from the timber harvest.

\section{Hunting}

Participant households expressed great concern over the potential impacts of logging on game animals. When listing the costs and benefits of the CCP logging (Table 3), three of the communities anticipated a decline in hunting success rates after logging. A fourth, Santo Antonio, had a mixed response-although many individuals cited a decline in hunting after the logging, others claimed that any perceived declines were due to overhunting by community members, independent of logging activities. After an active debate, most agreed that the presence of hunters in the area (due to creation of INCRA settlements) had a greater impact on game abundance than the logging itself. They did, however, assert that certain animal species (e.g., deer (Mazama sp.) might be more susceptible to declines in response to the increased noise and human presence in the area caused by the logging, but they expected that populations would return after logging activities subsided.

Results from diaries and questionnaires show that the average annual household hunting rate in CCPlogged and non-CCP communities are not statistically different (Table 4). The total number of animals caught each year per household (from diaries) showed no statistical difference between CCP-logged and non-CCP communities. The number of animals caught in non-CCP communities averaged $9.5 \pm 13.0$, and in CCP-logged communities averaged $11.9 \pm$ 13.6. Although extensive inter-household variation in the number of animals caught $(\mathrm{min}=0$ animals; $\max =48$ animals) may influence the lack of statistical significance of the results, there was no statistical difference between non-CCP and CCP-logged communities even when non-hunters and outliers (>2 sd above the mean) were removed from analysis. In terms of the mass of meat caught annually, there is also no significant difference between CCP-logged and non-CCP communities. This lack of significant difference for weight also remains consistent when outliers are removed from the analysis. Bi-weekly questionnaires of hunting success rates showed hunting success for $42 \%$ of trips in CCP-logged communities and $49 \%$ in nonCCP, but they are not statistically different. Hunter effort (total hours spent hunting divided by total number animals caught, calculated for each hunter) was $10.2 \pm 10(n=20)$ in CCP-logged communities and $8.8 \pm 9(n=25)$ in non-CCP communities and not significantly different.

Two of the communities (Piranha (non-CCP) and Santo Antonio (CCP-logged)) spent a markedly longer time per animal $(12.5 \mathrm{~h})$ than the other three communities $(6.7 \mathrm{~h})$. When asked about this discrepancy, participants in the results presentation meeting in São João suggested the potential role of deer hunting - hunters who focus on deer tend to spend a longer time in the forest whereas those who spend less time are likely to take home whatever game animal they come across (e.g., agouti (Dasyprocta sp.), game birds, etc). Results from diaries seem to support this theory: deer comprised $26 \%$ of the animals caught in Piranha and $13 \%$ in Santo Antonio whereas in the other communities they represented $<6 \%$ of the total hunt. Although the numbers of animals and total amount of meat caught do not differ between CCP-logged and nonCCP communities, the taxa caught differ significantly (Chi-square $=11.39, \mathrm{df}=3, p<0.01$ ). Large-bodied animals (tapirs (Tapirus sp.), peccaries (Tayassu sp.), deer, and monkeys (Cebidae) are similarly important in CCP-logged and non-CCP communities $(21 \%$ vs. $18 \%$ of animals caught; Fig. 2). Medium mammals (large rodents and armadillos (Dasypus sp.) and birds were caught more often in non-CCP communities whereas reptiles (specifically Geocheleone sp.) were caught more often in the CCP-logged communities.

In response to a one-time questionnaire on hunting behaviors, respondents reported hunting $6.4 \pm 5.5$ times a month with an average success of $3.4 \pm 2.5$ times for every 10 hunting trips. There was no significant difference between reported frequencies or success rates in CCP-logged and non-CCP communities (Table 5). Respondents in both CCPlogged and non-CCP communities reported a substantial decline in hunting success rates since their arrival in the community (non-CCP: 53.6 
Table 2. Percentage of households recording use of the top 10 ranked NTFPs in CCP-logged and non-CCP colonist communities. $(\mathrm{G}=$ game animal, $\mathrm{F}=$ forest fruit, $\mathrm{M}=$ medicinal product, $\mathrm{C}=$ construction/handicraft material.) Percent use is calculated based on diary records (CCP logged: $n=22$; non-CCP: $n=26)$ such that it is the number of households who recorded use of a product at least once divided by the total number of participants for CCP-logged communities and non-CCP communities.

\begin{tabular}{lclc}
\hline \hline & CCP logged & & \\
Product & Percentage & Product & Non-CCP \\
\hline Deer (G) & $83 \%$ & Paca (G) & $64 \%$ \\
Tortoise (G) & $74 \%$ & Armadillo (G) & $54 \%$ \\
Agouti (G) & $70 \%$ & Agouti (G) & $50 \%$ \\
Armadillo (G) & $61 \%$ & Tortoise (G) & $50 \%$ \\
Peccary (G) & $43 \%$ & Brazil Nut (F) & $46 \%$ \\
Paca (G) & $43 \%$ & Açaí (F) & $39 \%$ \\
Bacaba (F) & $35 \%$ & Peccary (G) & $32 \%$ \\
Brazil Nut (F) & $35 \%$ & Titica (C) & $32 \%$ \\
Andiroba (M) & $30 \%$ & Deer (G) & $29 \%$ \\
Titica (C) & $30 \%$ & Piquiá (F) & $18 \%$ \\
\hline
\end{tabular}

$\pm 36.8 \%$, CCP-logged: $51.9 \pm 27.8 \%$ ) with no significant difference between the two $(\mathrm{K}-\mathrm{S}, \mathrm{Z}=$ $0.805, p=0.537)$. In CCP-logged forest, hunters walked an average of $2.0 \pm 0.9 \mathrm{~km}$ whereas in non$\mathrm{CCP}$ forest, they walked $1.3 \pm 0.8 \mathrm{~km}$. As such, hunters in the CCP-logged forests were walking 1.5 times as far as their non-CCP counterparts but the difference was not statistically significant (one-way ANOVA, $\mathrm{F}=3.195, p=0.090)$.

\section{Forest Fruit}

Some community members predicted a decline in fruit harvests after logging due to a reduction in the number of available fruit trees. However, no significant difference was found in recorded annual household forest fruit harvests between communities with CCP logging $(9.8 \pm 13.2 \mathrm{~kg})$ and without $(13.5$ $\pm 15.9 \mathrm{~kg})(\mathrm{M}-\mathrm{W}, \mathrm{Z}=-0.908, p=0.364)$. Fruit harvests showed high inter-household variability and were on such a small scale (average annual household harvest across communities $=11.8$ $\pm 14.7 \mathrm{~kg}$ ) that any changes would be difficult to detect. Fruit harvests in the study communities were most often opportunistic: a handful of fruits eaten while out on a hunt or a small harvest on return from the fields. In addition, their use for purely subsistence purposes means they were often perceived as having little to no value. As a result, they are likely to be underreported in resource diaries, making accurate assessment of total harvests difficult.

Although many fruiting trees were logged, only three species scored among the 10 most important for the participant communities (in a PRA scoring exercise, see Menton (2006)) were logged: piquiá (Caryocar villosum), jutaí (Hymanaea intermedia), and jatobá (Hymanaea courbaril). Other important fruit trees included Brazil nut trees (Bertholletia excelsa), which are protected by law, and palms (e. g., açaí (Euterpe oleracea), bacaba (Oenocarpus bacaba)), which are not logged. 
Table 3. Community perceptions of logging impacts expressed at PRA workshops. (CCP logged = already participating in full-scale logging; Beginning CCP logging = some sales from agricultural clearings, signed contracts; non-CCP = have yet to sign contracts; $\mathrm{X}$ - Community members disagreed as to whether or not there had been hunting declines)

\begin{tabular}{|c|c|c|c|c|c|}
\hline \multirow[t]{3}{*}{ Impacts } & \multicolumn{5}{|c|}{ Colonist Community } \\
\hline & \multicolumn{2}{|c|}{ CCP logged } & \multicolumn{2}{|c|}{ Beginning CCP } & \multirow{2}{*}{$\begin{array}{l}\text { Non-CCP } \\
\text { São João }\end{array}$} \\
\hline & Anta & Santo Antonio & Piranha & São Mateus & \\
\hline \multicolumn{6}{|l|}{ Positive } \\
\hline Roads & $\bullet$ & - & $\bullet$ & $\bullet$ & $\bullet$ \\
\hline Income & $\bullet$ & $\bullet$ & $\bullet$ & $\bullet$ & • \\
\hline Loans/advances & $\bullet$ & $\bullet$ & & $\bullet$ & • \\
\hline $\begin{array}{l}\text { Community } \\
\text { infrastructure }\end{array}$ & $\bullet$ & $\bullet$ & & & $\bullet$ \\
\hline $\begin{array}{l}\text { Transportation } \\
\text { (rides) }\end{array}$ & - & $\bullet$ & & & \\
\hline Land demarcation & $\bullet$ & & & & $\bullet$ \\
\hline $\begin{array}{l}\text { Prevention of } \\
\text { illegal logging }\end{array}$ & & & $\bullet$ & & $\bullet$ \\
\hline Trails & & & & & $\bullet$ \\
\hline Employment & & $\bullet$ & & & \\
\hline $\begin{array}{l}\text { Knowledge of } \\
\text { forest }\end{array}$ & & $\bullet$ & & & \\
\hline \multicolumn{6}{|l|}{ Negative } \\
\hline Hunting decline & $\bullet$ & $X$ & & - & - \\
\hline Low price & - & & $\bullet$ & & \\
\hline Loss of freedom & & & $\bullet$ & & $\bullet$ \\
\hline Fruit decline & & $\bullet$ & & & \\
\hline $\begin{array}{l}\text { Failure to meet } \\
\text { promises }\end{array}$ & & & & $\bullet$ & \\
\hline No timber in future & & & & & $\bullet$ \\
\hline $\begin{array}{l}\text { Pollution of } \\
\text { streams }\end{array}$ & $\bullet$ & & & & \\
\hline
\end{tabular}


Table 4. Hunting rates in CCP-logged and non-CCP communities. $\mathrm{HH}=$ household; animals/yr and $\mathrm{kg}$ meat/yr are based on diary records (CCP logged: $n=22$; non-CCP: $n=26$ ). Hours hunt/animal and success rate (percentage of hunting trips in which at least one animal was caught) are based on bi-weekly questionnaires (CCP logged: respondents $=26$, total number of surveys $=324$; non-CCP: respondents $=$ 30 , total number of surveys $=387$ ).

\begin{tabular}{lcccc}
\hline \hline & CCP logged & Non-CCP & $\begin{array}{c}\text { Kolmogorov-Smirnov } \\
\text { Z }\end{array}$ & $p$-value \\
\hline Animals/HH/yr & $11.9 \pm 13.6$ & $9.5 \pm 13.0$ & 1.063 & 0.209 \\
without outliers & $9.1 \pm 10.6$ & $6.8 \pm 9.0$ & 1.101 & 0.177 \\
Kg meat/HH/yr & $74 \pm 88$ & $73 \pm 172$ & 1.094 & 0.182 \\
without outliers & $60 \pm 60$ & $43 \pm 61$ & 1.109 & 0.171 \\
Hunting success & $42 \%$ & $49 \%$ & 0.678 & 0.747 \\
Hunting effort (h) & $10.2 \pm 10$ & $8.8 \pm 9$ & 0.715 & 0.687 \\
\hline
\end{tabular}

\section{Perceptions of Logging Impacts and Use of Income}

During participatory workshops, community members outlined the overall impacts of the logging (Table 3), highlighting both the more obvious primary benefits (e.g., income, roads) and secondary perks (e.g., help with community infrastructure (wells, halls), advances on payment, and land demarcation). Negative aspects of involvement in the logging contracts included: concern about lost freedom, being bound both to the land (cannot sell their land during the contract period of 3 years) and the logging company; and objections regarding the price received for the timber. Some communities also noted reductions in hunting success rates and fruit harvests.

During workshops in the CCP-logged communities, the overwhelming majority $(96 \%, n=35)$ voted that the CCP logging had been worthwhile. When asked individually in questionnaires, all respondents who had already received payment from the management area (average income from 80-ha plot $=\mathrm{R} \$ 5900$ $\pm 2600 ; \mathrm{n}=10$ ) responded positively. Those who had only received payment from timber harvested from agricultural clearings (average income per 3ha plot $=\mathrm{R} \$ 1200 \pm \mathrm{R} \$ 1100 ; n=14)$, however, were more varied in their response: $21 \%$ felt very positively, $36 \%$ felt positively, $29 \%$ felt it was of little value, and $14 \%$ felt it was not worthwhile. Those who had yet to sell any timber $(n=9)$ were optimistic, with $89 \%$ responding positively and only one respondent responding that it was not worthwhile. Negative impressions of the logging were, in large part, in response to the opinion that they were receiving an unfair price for the timber ( $n=32,94 \%$ felt price was unfair). When asked whether or not they understood the logging process, $50 \%$ reported little or no understanding.

The one-off income from timber sales (approximately $\mathrm{R} \$ 8000)$ equals more than 8 years of average household agricultural sales ( $\mathrm{R} \$ 964 \pm 920, n=46)$. On an individual basis, income from timber sales was sufficient for investment in agricultural production (e.g., purchase of black pepper (Piper nigrum) seedlings, construction of a manioc-flourprocessing structure) or household infrastructure (see Table 6). Of the households interviewed that had sold timber from their entire forest reserve $(n=$ $10)$, all households used the funds for general expenses and the vast majority also used the money for house construction (70\%) and investment in agricultural production (90\%). Investment in black pepper (33\%) and "farinha" processing (44\%) were the most frequent investments cited. Almost all households that had sold timber from agricultural clearings $(n=28)$ used the funds for general expenses $(86 \%)$ and some used the funds for house 
Fig. 2. Hunting rates in CCP-logged and non-CCP communities by game animal type. Large mammals include peccaries, deer, tapir, and monkeys. Medium mammals include armadillos, agouti, paca, and other large rodents. Birds include all game birds. Reptiles include tortoises.

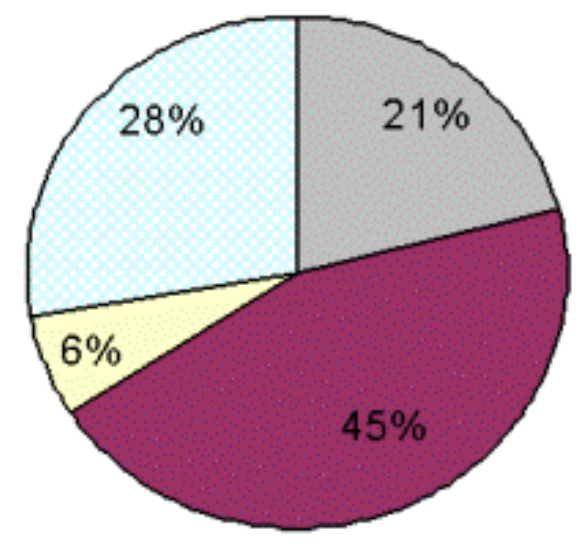

CCP-Logged

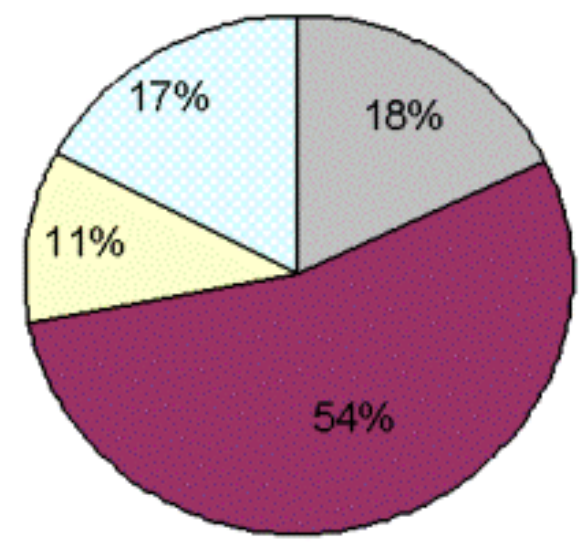

large-bodied mammals medium mammals

birds

reptiles construction $(32 \%)$ and medicine or doctor's fees $(32 \%)$. Less than half $(39 \%)$ invested the funds in agricultural production, with black pepper (45\%) and farinha $(18 \%)$ as the most commonly cited investments. Across communities, households that sold pepper recorded significantly higher annual agricultural sales $($ mean $=\mathrm{R} \$ 1258 \pm 1112, n=21)$ than those who did not (mean $=\mathrm{R} \$ 716 \pm 657, n=25)$ (K-S, $\mathrm{Z}=1.364, p=0.048)$. However, if the two wealthiest outliers ( $>2$ sd above the mean) are excluded, the relationship is no longer significant $(\mathrm{K}-\mathrm{S}, \mathrm{Z}=1.162, p=0.134)$. Only $20 \%$ of households raised cattle, with an average herd of $2 \pm 1$ animals, indicating that, at least in the short term, logging income was not widely used to invest in cattle.

\section{DISCUSSION}

Participants in diary studies often claim to be recording their activities on a regular basis even though such consistency may not be the case (Stone et al. 2003). Some respondents fail to record all resource use (Hill and Davies 2001) whereas others may exaggerate, especially regarding socially desirable activities (Bernard et al. 1984). Although studies of hunting rates can be plagued by issues of honesty in reporting, both in terms of underreporting due to fear of reporting illegal activities or overreporting to impress others, these issues are consistent across communities such that participation in the CCP logging project should not bias diary reporting in any one direction. In this study, diaries estimate an average of annual hunts of 10 to 12 animals per household. Another study of hunting rates in the Amazon using diaries found an average of 12 animals per household (Shanley 1999) and PRA estimates in one community in the region also estimated 12 animals per household (Menton 2003). As such, although the data may not reflect a precise estimate of hunting rates, they show similarities with results from other studies in the region.

The lack of significant difference in hunting between communities with and without $\mathrm{CCP}$ contracts indicates that RIL may have limited impacts on game-animal populations. Although the sample size and high inter-household variation are likely to have contributed to the lack of statistically significant results, the means were within $20 \%$ of each other for hunting rates and $30 \%$ for fruit harvests, which indicates that the CCP logging is unlikely to have caused large changes in harvest rates. Studies of conventional logging have shown that whereas some species suffer population 
Table 5. Hunting frequency, success rates and distances travelled in CCP-logged and non-CCP communities according to household survey responses. Communities: CCP logged: $n=2$; non-CCP: $n=3$. Success rate is based on household heads' estimates of the number of hunting trips out of 10 attempts wherein an animal was caught. Times Hunt and Distance Walked are based on household heads' estimates.

\begin{tabular}{lcccc}
\hline \hline Community Type & $\begin{array}{c}\text { Times Hunt per } \\
\text { Month }\end{array}$ & $\begin{array}{c}\text { Success Rate out of 10 } \\
\text { Trips - Current }\end{array}$ & $\begin{array}{c}\text { Success Rate out of 10 } \\
\text { Trips - when Arrived }\end{array}$ & $\begin{array}{c}\text { Average Distance Walked } \\
\text { during Hunt (km) }\end{array}$ \\
\hline Non-CCP & $6.2 \pm 5.5$ & $3.4 \pm 2.2$ & $7.4 \pm 4.0$ & $1.3 \pm 0.8$ \\
CCP logged & $6.4 \pm 5.6$ & $3.4 \pm 2.7$ & $6.9 \pm 2.6$ & $2.0 \pm 0.9$ \\
All Communities & $6.4 \pm 5.5$ & $3.4 \pm 2.5$ & $7.0 \pm 3.1$ & $1.7 \pm 0.9$ \\
\hline
\end{tabular}

declines after logging (Heydon and Bulloh 1997, Knop et al. 2004), others may increase (Ochoa 2000, Lambert et al. 2005), whereas still others may be unaffected (see review in Azevedo-Ramos et al. 2002). A study of the short-term effects of RIL on fauna in eastern Pará found overall effects on populations to be minor, with no changes in richness, abundance, or composition of mammals (Azevedo-Ramos et al. 2006). As such, reductions in alteration of forest structure due to RIL may make logging compatible with conservation of gameanimal communities. A parallel study in the settlement forests (Menton 2006) found no difference in population densities of most game animals in RIL-logged vs. unlogged forests, which further supports the conviction of some community members that the logging was not responsible for any perceived declines. Also, as stated in the results, both CCP-logged and non-CCP communities reported equivalent declines in hunting success rates since arrival in the community, which may indicate that the logging was not the key factor leading to hunting declines.

The lack of changes in fruit harvests is most likely due, in part, to the small-scale nature of harvests and low logging impacts. Although felling damage and changes in microclimate may have indirect effects on non-timber fruit trees, the impacts are likely to be minimal, especially as the palm fruit trees tend to concentrate along stream beds, which are exempt from logging activities. At low NTFP-harvest rates, preservation of a small number of trees should be sufficient to meet the demands of the study households.
The discrepancy between community members' perceptions of changes in resource use (declines in game and fruit harvests) and results from diaries and questionnaires offer an important area for further investigation. Although questionnaires that asked participants to estimate their hunting success rate yielded estimates of $34 \%$, bi-weekly questionnaires of hunting activities yielded success rates of $42 \%$ $49 \%$. Although PRA suggested declines in the number of animals caught after logging, diaries and questionnaires showed no statistical difference. In some of the study communities, a number of individuals claimed that the reductions in hunting success rates in recent years were caused by unsustainable hunting activities and not by the logging itself. Upon hearing the results of the study, many other community members were convinced that was the case. Studies of the impacts of hunting pressure on game populations show significant decreases in populations of many species in community forests (Peres 2000, Peres and Lake 2003). The effects of hunting are likely to be greater than that of logging (Lopes and Ferrari 2000, Peres and Lake 2003). As the presence of loggers often increases hunting pressure because of the construction of roads (Wilkie et al. 2000), it is important to begin to decouple the effects of hunting and logging. (Although loggers are often active hunters, thereby further increasing hunting pressure, MAFLOPS strictly prohibits its workers from hunting during their free time to the extent that those found hunting are fired on the spot.)

The inter-household variability in resource use among study households creates limitations in forming more general conclusions regarding the 
Table 6. Investment of logging income.

Income Source

\begin{tabular}{lcc} 
Use & Managed Forest & Clearings \\
\hline General Expenses & $100 \%$ & $86 \%$ \\
House Construction & $70 \%$ & $32 \%$ \\
Medical Expenses & $0 \%$ & $32 \%$ \\
\hline
\end{tabular}

effects of CCP logging on hunting rates and fruit harvests based on the timeframe and sample size of this study. A larger sampling of households in the region may have led to greater statistical precision. Nevertheless, the lack of statistically significant differences between CCP-logged communities and non-CCP communities indicates that if logging does alter NTFP use, it is unlikely to do so at an order of magnitude that would significantly compromise livelihoods in the study communities. Evaluation of the long-term sustainability of the CCP logging project will require further study, with attention to household retention in the settlement community, deforestation rates of their landholdings, household economies, and continued use of and access to NTFPs.

\section{CONCLUSION}

Participants in the CCP logging earned timberharvest incomes equivalent to 8 years of agricultural production without significant differences in NTFP harvest rates from those who did not participate. Although community members perceived a decline in hunting success rates and fruit harvests, diaries and questionnaire data show no difference between $\mathrm{CCP}$-logged and non-CCP communities. When presented with the results of the questionnaires and diaries, all of the communities showed general agreement with the overall conclusions, engaging in discussions about other reasons behind their perceptions of hunting declines. Improvements in infrastructure and income from timber sales brought benefits without significantly altering household use of forest resources. The study households harvested small quantities of NTFPs. Combined with the use of RIL techniques to minimize changes in forest structure, and thereby changes in resource abundance and access, the logging did not greatly affect harvest rates in the study communities. A similar study with more forest-dependent households (e.g., traditional populations, CavigliaHarris and Sills 2005) or of conventionally logged forest might yield very different results. As it stands, RIL in communities that do not depend heavily on forest resources could bring livelihood benefits without significant costs in terms of the use of and access to NTFPs. The lack of a significant change in resource use may also indicate that the changes in household wealth at the level of this project do not alter the opportunity costs of NTFP harvests. Nevertheless, further study will be necessary to evaluate the long-term implications of participation in this type of CCP logging project and its suitability for replication in other settlement areas. Assessment of its potential role in sustainable development programs in these communities will depend on the long-term status of the participant households.

\section{GROUNDED SPECULATION}

The results from this study provide a snapshot of the immediate impacts of the CCP logging project on study households. Results that show increased household income without reductions in NTFP harvests must be tempered with caution regarding the uncertainty of the long-term implications of the logging project. A one-time windfall of the equivalent of 8 years of agricultural sales, or $\mathrm{R} \$ 8000$, could have profound implications for household-level economics and the long-term sustainability of the settlement communities. In many frontier areas, households reside only temporarily on their lands, moving on to new 
frontiers where they deforest new areas (Schmink and Wood 1992, Walker et al. 2002). Those who stay often turn to cattle ranching, a low-risk, highly liquidable alternative to perennial agriculture, which leads to increased deforestation (Arima et al. 2006, Browder et al. 2008).

We suggest a number of revisions to the FF model that could promote a more viable and sustainable strategy for forest management and conservation in these communities. First, although $\mathrm{R} \$ 8000$ is an impressive sum of cash for these households, the one-time nature of its distribution could encourage "log-and-run" behavior (Zarin et al. 2007). If logging income could be dispersed over several years, it could encourage more long-term investment by the households. Second, because the timber is harvested and transported to sale to a thirdparty sawmill, the economic benefits from processing the raw materials are not accrued by the households nor the logging company. Investment in locally based small sawmills could significantly increase income from the logging project and provide incentives for household retention in the community. Third, the households currently underutilize the NTFP base available in their forests. Although MAFLOPs initiated a project to pay households to harvest and process Carapa guianensis oil (andiroba), at the time of the study, few households were benefiting from this potential source of income. Other projects that take advantage of NTFPs could help improve livelihoods between cutting cycles and thus increase household retention.

The potential value of this CCP logging as a forest management model lies in its comparison with other logging regimes in the region. Illegal loggers often pay as little as $\mathrm{R} \$ 10$ per tree, approximately onesixth of the value paid by MAFLOPs, and do not provide the improvements in infrastructure installed by the FF project. Conventional logging, although sometimes legal, leads to significantly greater damage to the remnant forest (Schulze and Zweede 2006) and thus potentially greater ramifications for NTFP harvests. Further studies comparing the livelihood implications of different logging regimes would help clarify the costs and benefits of incorporating forest management in development strategies for settlement communities. Long-term studies, of the FF model and other forest management projects, will be necessary to underline the key factors that could promote the sustainability of communities along the frontier.
Responses to this article can be read online at: http://www.ecologyandsociety.org/voll4/iss 1/art39/ responses/

\section{Acknowledgments:}

We would like to thank the study communities, MAFLOPS, field assistants, and administrative staff at IPAM, and the administrative and logistical support staff of Project LBA-Ecology. Financial support for this research was provided by the Gordon and Betty Moore Foundation, the U.S. Agency for International Development, and the National Science Foundation Graduate Fellowship. We also thank Paul Lefebvre for the map and Jan Salick, Rajindra Puri, Stephen Perz, and two anonymous reviewers for comments on earlier drafts.

\section{LITERATURE CITED}

Arima, E., P. Barreto, and M. Brito. 2006. Pecuária na Amazônia, tendências e implicações para a conservação ambiental. Instituto do Homen et Meio Ambiente da Amazõnia (IMAZON), Belém, Brazil.

Assies, W. 1997. Going nuts for the rainforest : nontimber forest products, forest conservation and sustainability in Amazonia. Thela, Amsterdam, The Netherlands.

Azevedo-Ramos, C., O. Carvalho, Jr., and R. Nasi. 2002. Animal indicators: a tool to assess biotic integrity after logging in tropical forests? CIFOR Report. IPAM, Belém, Brazil.

Azevedo-Ramos, C., O. de Carvalho, and B. D. do Amaral. 2006. Short-term effects of reducedimpact logging on eastern Amazon fauna. Forest Ecology and Management 232(1-3):26-35.

Barreto, P. 1998. Costs and benefits of forest management for timber production in eastern Amazonia. Forest Ecology and Management 108:9-26.

Barreto, P., C. Souza, Jr., A. Anderson, R. Salomão, J. Wiles, and R. Noguerón. 2005. Human pressure in the Brazilian Amazon. Instituto 
do Homen et Meio Ambiente da Amazõnia (IMAZON) - State of the Amazon 3. IMAZON, Belém, Brazil.

Bentes-Gama, M., V. B. V de Oliveira, A. H. Vieira, M. Locatelli, V. G. S. Rodrigues, I. M. Medeiros, and E. P. Martins. 2006. Fortalecimento do manejo florestal comunitário em assentamento rural na Amazônia Ocidental, Rondônia, Brasil. Anais do Congresso Latino Americano IUFRO 2. La Serena, Chile.

Bernard, H. R., P. Killworth, D. Kronenfeld, and L. Sailer. 1984. The problem of informant accuracy - the validity of retrospective data. Annual Review of Anthropology 13:495-517.

Browder, J. O., M. A. Pedlowski, R. Walker, R. H. Wynne, P. M. Summers, A. Abad, N. BecerraCordoba, and J. Mil-Homens. 2008. Revisiting theories of frontier expansion in the Brazilian Amazon: a survey of the colonist farming population in Rondonia's post-frontier, 1992-2002. World Development 36:1469-1492.

Campos, M. T., and D. C. Nepstad. 2006. Smallholders, the Amazon's new conservationists. Conservation Biology 20(5):1553-1556.

Cavendish, W. 2002. Quantitative methods for estimating the economic value of resource use to rural households. Pages 17-65 in B. M. Campbell and M. K. Luckert, editors. Uncovering the hidden harvest: valuation methods for woodland and forest resources. Earthscan, London, UK.

Caviglia-Harris, J. L., and E. O. Sills. 2005. Land use and income diversification: comparing traditional and colonist populations in the Brazilian Amazon. Land Economics 32(1):221-237.

Cooke, B., and U. Kothari, editors. 2001. Participation: the new tyranny? Zed Books, London, UK.

Crook, C., and R. A. Clapp. 1998. Is marketoriented forest conservation a contradiction in terms? Environmental Conservation 25(2):131145.

D'Oliveira, M. V.N., and E. M. Braz. 2006. Estudo da dinâmica da floresta no projeto de manejo florestal comunitário do PC Pedro Peixoto na Amazônia Ocidental. Acta Amazonica 36(2):177182.
D'Oliveira, M. V. N., E. M. Braz, D. F. R. P. Burslem, and M. D. Swaine. 1998. Small-scale natural forest management: a new model for small farmers in the Brazilian Amazon. Tropical Forest Update 8(1):5-7.

Dovie, D. B. K. 2003. Whose involvement?-can hierarchical valuation scheme intercede for participatory methods for evaluating secondary forest resource use? Forest Policy and Economics 5(3):265-283.

Grieg-Gran, M., I. Guijt, and B. Peutalo. 2002. Local perspectives on forest values in Papua New Guinea: the scope for participatory methods. International Institute for Environment and Development (IIED), London, UK.

Guariguata, M. R., P. Cronkleton, P. Shanley, and P. L. Taylor. 2008. The compatibility of timber and non-timber forest product extraction and management. Forest Ecology and Management 256:1477-1481.

Heydon, M. J., and P. Bulloh. 1997. Mousedeer densities in a tropical rainforest: the impact of selective logging. Journal of Applied Ecology 34 (2):484-496.

Hill, R. J., and P. S. W. Davies. 2001. The validity of self-reported energy intake as determined using the doubly labeled water technique. British Journal of Nutrition 85(4):415-430.

Homma, A. K. O. 1996. Modernization and technological dualism in the extractive economy in Amazonia. Pages 59-81 in M. Ruiz-Perez and J. E. M. Arnold, editors. Current issues in non-timber forest product research. CIFOR, Indonesia.

Humphries, S. S., and K. A. Kainer. 2006. Local perceptions of forest certification for communitybased enterprises. Forest Ecology and Management 235(1-3):30-43.

Johns, J. S., P. Barreto, and C. Uhl. 1996. Logging damage during planned and unplanned logging operations in the eastern Amazon. Forest Ecology and Management 89:59-77.

Knop, E., P. I. Ward, and S. A. Wich. 2004. A comparison of orangutan density in a logged and unlogged forest on Sumatra. Biological Conservation 120(2):183-188. 
Laird, S. A. 1995. The natural management of tropical forests for timber and non-timber products. OFI Occasional Papers (49), Oxford, UK.

Laird, S. A., and D. A. Posey. 2002. Professional society standards for biodiversity research: codes of ethics and research guidelines. Pages 16-38 in S. A. Laird, editor. Biodiversity and traditional knowledge: equitable partnerships in practice. Earthscan, London, UK.

Lambert, T. D., J. R. Malcolm, and B. L. Zimmerman. 2005. Effects of mahogany (Swietenia macrophylla) logging on small mammal communities, habitat structure, and seed predation in the southeastern Amazon Basin. Forest Ecology and Management 206(1-3):381-398.

Lawrence, A. 2003. No forest without timber? International Forestry Review 5(2):87-96.

Lima, E., A. A. Leite, D. Nepstand, K. Kalif, C. Azevedo-Ramos, C. Pereira, A. Alencar, U. L. Silva, Jr., and F. Merry. 2003. Florestas familiares: um pacto sócio-ambiental entre a indústria madeireira e a agricultura familiar na Amazônia. IPAM, Belém, Pará, Brazil.

Lima, E., F. Merry, D. Nepstad, G. Amacher, C. Azevedo-Ramos, P. Lefebvre, and F. Resque. 2006. Searching for sustainability. Environment 48:26-38.

Lipper, L. 2000. Forest degradation and food security. Unasylva 202. [online] URL: http://www. fao.org/docrep/x7273e/x7273e05.htm\#P0 0.

Lopes, M. A., and S. F. Ferrari. 2000. Effects of human colonization on the abundance and diversity of mammals in eastern Brazilian Amazonia. Conservation Biology 14(6):1658-1665.

Mayers, J., S. Vermeulen, and International Institute for Environment and Development (IIED). 2002. Company-community forestry partnerships: from raw deals to mutual gains?: an international review with proposals for improving forests, enterprise and livelihoods. Earthprint, Stevenage, UK.

McSweeney, K. 2002. Who is "forest-dependent"? Capturing local variation in forest-product sales, Eastern Honduras. Professional Geographer 54 (2):158-174.
Medina, G., and P. Shanley. 2004. Big trees, small favors: loggers and communities in Amazonia. Bois et Forêts des Tropiques 282(4):19-25.

Menton, M. C. 2003. Effects of logging and nontimber forest product extraction in the Brazilian Amazon: community perceptions of change. International Forestry Review 5(2):97-105.

Menton, M. C. S. 2006. Company-community logging contracts in the Brazilian Amazon: effects on liveilhoods and use of NTFPs in colonist communities. University of Oxford, Oxford, UK.

Merry, F., G. Amacher, D. Macqueen, M. Guimares dos Santos, E. Lima, and D. Nepstad. 2006. Collective action without collective ownership: community associations and logging on the Amazon frontier. International Forestry Review 8:211-221.

Merry, F., E. Lima, G. Amacher, O. Almeida, A. Alves, and M. R. G. dos Santos. 2004. Overcoming marginalization in the Brazilian Amazon through community association: case studies of forests and fisheries. International Institute for Environment and Development (IIED), Edinburgh, UK.

Ministério do planejamento, orçamento e gestã. 2002. Brasil: 1994-2002: Projetos e realizações do governo. Ministério do planejamento, orçamento e gestã, Brasilia, Brazil.

Moran, E. F. 1996. Deforestation in the Brazilian Amazon. Pages 149-164 in L. E. Sponsel, T. N. Headland, and R. C. Bailey, editors. Tropical deforestation: the human dimension. Columbia University Press, New York, New York, USA.

Nepstad, D., A. Alencar, A. C. Barros, E. Lima, C. Azevedo-Ramos, S. Lima, and P. Lefebvre. 2004a. Governing the Amazon timber industry. Pages 388-414 in D. Zarin, F. J. Putz, M. Schmink, and J. Alavalapati. Working forests in the neotropics: conservation through sustainable management. Columbia University Press, New York, New York, USA.

Nepstad, D., C. Azevedo-Ramos, E. Lima, D. McGrath, C. Pereira, and F. Merry. 2004b. Managing the Amazon timber industry. Conservation Biology 18(2):575-577. 
Ochoa, J. 2000. Effects of logging on smallmammal diversity in the lowland forests of the Venezuelan Guyana region. Biotropica 32(1):146164.

Pattanayak, S. K., and E. O. Sills. 2001. Do tropical forests provide natural insurance? The microeconomics of non-timber forest product collection in the Brazilian Amazon. Land Economics 77:595-613.

Peres, C. A. 2000. Effects of subsistence hunting on vertebrate community structure in Amazonian forests. Conservation Biology 14(1):240-253.

Peres, C. A., and I. R. Lake. 2003. Extent of nontimber resource extraction in tropical forests: accessibility to game vertebrates by hunters in the Amazon basin. Conservation Biology 17(2):521535.

Pinard, M. A., F. E. Putz, J. Tay, and T. E. Sullivan. 1995. Creating timber harvesting guidelines for a reduced impact-logging project in Malaysia. Journal of Forestry 93:41-45.

Rival, L. 2005. From global forest governance to privatised social forestry: company-community partnerships in the Ecuadorian Choco. Pages 253270 in M. B. Likisky, editor. Privatising Development. Martinus Nijhoff Publishers, Leiden, The Netherlands.

Ros-Tonen, M. A. F., T. van Andel, C. Morsello, K. Otsuki, S. Rosendo, and I. Scholz. 2008. Forest-related partnerships in Brazilian Amazonia: there is more to sustainable forest management than reduced impact logging. Forest Ecology and Management 256:1482-1497.

Ruiz-Perez, M., and J. E. M. Arnold. 1996. Current issues in non-timber forest products research. Proceedings of the workshop "Research on NTFPs. ” Hot Springs, Zimbabwe, 1995. CIFOR, Jakarta, Indonesia.

Sá, C. P., H. J. B. Araújo, J. C. Santos, E. M. Braz, E. M. Miranda, and P. R. Souza. 1998. Insumos necessários para o manejo florestal em áreas de reserva legal no Acre. Embrapa CPAF/AC Instruções Técnicas 10. Acre, Brasil.

Salick, J., A. Mejia, and T. Anderson. 1995. Nontimber forest products integrated with natural forest management, Rio San Juan, Nicaragua. Ecological Applications 5(4):878-895.

Schmink, M., and C. H. Wood. 1992. Contested frontiers in Amazonia. Columbia University Press, New York, New York, USA.

Schulze, M., and J. Zweede. 2006. Canopy dynamics in unlogged and logged forest stands in the eastern Amazon. Forest Ecology and Management 236:56-64

Shanley, P. 1999. As the forest falls: the changing use, ecology and value of non-timber forest resources for Caboclo communities in eastern Amazonia. Dissertation. University of Kent, Canterbury, UK.

Shanley, P. 2000. Extending ecological research to meet local needs: a case from Brazil. In T. C. H. Sunderland and L. E. Clark, editors. Non-wood forest products in central Africa: current research and issues and prospects for conservation and development. Food and Agriculture Organization, Rome, Italy. [online] URL: http://www.fao.org/doc rep/x2161e/x2161e10.htm.

Shanley, P., and S. A. Laird. 2002. "Giving back": making research results relevant to local groups and conservation. Pages 102-124 in S.A. Laird, editor. Biodiversity and traditional knowledge: equitable partnerships in practice. Earthscan, London, UK.

Shanley, P., L. Luz, and M. Cymerys. 2002. Subsistence issues: the interface of timber and nontimber resources: declining resources for subsistence livelihoods (Brazil). Pages 313-321 in P. Shanley, A. R. Pierce, S. A. Laird, and A. Guillén, editors. Tapping the green market: certification and management of non-timber forest products. Earthscan, London, UK.

Shanley, P., and G. Medina. 2005. Frutíferas e plantas úteis na vida amazônica. CIFOR, Instituto do Homen et Meio Ambiente da Amazõnia (IMAZON), Belém, Brazil.

Smith, N. J. H. 1982. Rainforest corridors: the Transamazon colonization scheme. University of California Press, Berkeley, California, USA.

Stone, A. A., S. Shiffman, J. E. Schwartz, J. E. Broderick, and M. R. Hufford. 2003. Patient compliance with paper and electronic diaries. 
Controlled Clinical Trials 24(2):182-199.

Uhl, C., A. Veríssimo, M. M. Mattos, Z. Brandinho, and I. C. G. Viera. 1991. Social, economic and ecological consequences of selective logging in an Amazonian frontier: the case of Tailândia. Forest Ecology and Management 46:243-273.

Vasquez, R., and A. H. Gentry. 1989. Use and misuse of forest-harvested fruits in the Iquitos area. Conservation Biology 3(4):350-361.

Vosti, S. A., E. M. Braz, C. L. Carpentier, M. V. N. D'Oliveira, and J. Witcover. 2003. Rights to forest products, deforestation and smallholder income: evidence from the western Brazilian Amazon. World Development 31(11):1889-1901.

Wallace, R. H. 2004. The effects of wealth and markets on rubber tapper use and knowledge of forest resources in Acre, Brazil. University of Florida, Gainesville, Florida, USA.

Walker, R., S. Perz, M. Caldas, and L. G. T. Silva. 2002. Land use and land cover change in forest frontiers: the role of household life cycles. International Regional Science Review 25:169199.

Watson, F. 1996. A view from the forest floor: the impact of logging on indigenous peoples in Brazil. Botanical Journal of the Linnean Society 122:7582.

Wilkie, D., E. Shaw, F. Rotberg, G. Morelli, and P. Auzel. 2000. Roads, development, and conservation in the Congo basin. Conservation Biology 14(6):1614-1622.

Wollenberg, E., and A. Ingles 1998. Incomes from the forest: methods for the development and conservation of forest products for local communities. CIFOR, Bogor, Indonesia.

Zarin, D. J., M. D. Schulze, E. Vidal, and M. Lentini. 2007. Beyond reaping the first harvest: management objectives for timber production in the Brazilian Amazon. Conservation Biology 21 (4):916-925. 